Jurnal Ilmiah Matematika dan Pendidikan Matematika (JMP)

Vol. 9 No. 2, Desember 2017, hal. 21-36

ISSN (Cetak) : 2085-1456; ISSN (Online) : 2550-0422; https://jmpunsoed.com/

\title{
ANALISIS KESTABILAN ENDEMIK MODEL EPIDEMI CVPD \\ (CITRUS VEIN PHLOEM DEGENERATION) \\ PADA TANAMAN JERUK
}

\author{
Tesa Nur Padilah \\ Universitas Singaperbangsa Karawang \\ tesa.nurpadilah@staff.unsika.ac.id \\ Najmudin Fauji \\ Universitas Singaperbangsa Karawang
}

\begin{abstract}
Orange fruits are important commodities in Indonesia. However, the efforts to increase production of oranges still have obstacles. One of them is because of CVPD (Citrus Vein Phloem Degeneration) disease. The spread of CVPD disease in orange plants can be modeled by mathematical model, that is epidemic model between orange plants as a host plant and Diaphorina Citri as a vector. In this model, predation response follows Holling Type II response function. The model is then analyzed by checking the stability of the equilibrium point and computing basic reproduction number. This model has an endemic equilibrium point. If the basic reproduction number is more than one then an endemic equilibrium point is locally asymptotic stable or epidemic which means that it occurs in the population. The simulation result of the model are in good agreement with the model behavior analysis.
\end{abstract}

Keywords: Basic Reproduction Number; Holling Type II; Epidemic Model; Equilibrium Point.

\begin{abstract}
ABSTRAK. Jeruk merupakan komoditas buah-buahan penting di Indonesia. Namun, usaha peningkatan produksi jeruk masih mengalami hambatan. Salah satunya dikarenakan penyakit CVPD (Citrus Vein Phloem Degeneration). Penyebaran penyakit CVPD pada jeruk dapat dimodelkan dalam suatu model matematis yaitu model epidemi antara tanaman jeruk sebagai inang dengan serangga Diaphorina Citri (kutu loncat) sebagai hama (vektor). Pada model ini, respon pemangsaan mengikuti fungsi respon Holling Tipe II. Analisis model dilakukan dengan menganalisis kestabilan titik ekuilibrium dan angka rasio reproduksi dasar. Model ini memiliki satu titik ekuilibrium endemik. Jika angka rasio reproduksi dasar lebih dari satu, maka titik ekuilibrium endemik stabil asimtotik lokal, yang berarti terjadi epidemi pada populasi. Simulasi model untuk penyakit ini sejalan dengan analisis perilaku model.
\end{abstract}

Kata Kunci: Angka Rasio Reproduksi Dasar; Holling Tipe II; Model Epidemi; Titik Ekuilibrium. 


\section{PENDAHULUAN}

Menurut Rizal et al. (2011), jeruk (Citrus sp) merupakan salah satu komoditi buah-buahan yang mempunyai peranan penting di pasaran dunia maupun dalam negeri, baik dalam bentuk segar maupun olahannya. Namun, produktivitas tanaman jeruk akan mengalami penurunan jika terkena serangan Diaphorina citri (kutu loncat). Penyakit menular yang disebabkan serangga ini dikenal sebagai penyakit CVPD (Citrus Vein Phloem Degeneration) (Wijaya et al., 2010). Menurut Balai Pengkajian Teknologi Pertanian (2002), penyakit ini disebabkan oleh bakteri Liberobacter asiaticum yang menghambat tanaman dalam menyerap nutrisi karena sel-sel phloem mengalami degenerasi. Selain ditularkan oleh serangga Diaphorina citri, penyebaran penyakit ini juga ditularkan oleh bibit jeruk yang terinfeksi CVPD.

Penyebaran penyakit CVPD dapat dimodelkan menjadi suatu model epidemi. Model epidemi merupakan model matematika yang dapat memberikan pemahaman tentang bagaimana penyakit menular dapat menyebar, menggali prinsip-prinsip umum yang mengatur dinamika penularan penyakit, dan mengidentifikasi parameter yang lebih penting dan sensitif untuk membuat prediksi yang dapat diandalkan dan memberikan strategi pencegahan serta pengendalian (Ma dan Li, 2009).

Model epidemi yang paling sederhana adalah model SI. Pada model ini, populasi yang diamati terbagi menjadi subpopulasi rentan $S$ (susceptible) serta subpopulasi terinfeksi dan menularkan I (infectives). Pada tahun 1927, KermackMckendrick memperluas model SI dengan menambahkan subpopulasi sembuh $R$ (recovery) (Ma \& Li, 2009). Selanjutnya Shi et al. (2014) menganalisis model penyakit tanaman yang membagi populasi tanaman inang menjadi subpopulasi inang rentan, inang terinfeksi dan menularkan, dan inang sembuh, serta membagi populasi hama (vektor) menjadi subpopulasi hama rentan dan hama terinfeksi dan menularkan. Laju pemangsaan pada model ini mengikuti laju pemangsaan yang sangat umum dimiliki oleh serangga yaitu fungsi respon Holling Tipe II karena tingkat pemangsaan dipengaruhi oleh ketersediaan mangsa. Pemangsaan meningkat seiring dengan meningkatnya ketersediaan mangsa, tetapi menurun 
saat mendekati kenyang sehingga waktu yang diperlukan pemangsa menjadi lebih lama (Holling, 1959). Berdasarkan model yang diperoleh, titik ekulibrium bebas penyakit dan titik ekulibrium endemik serta angka rasio reproduksi dasar kemudian ditentukan. Selanjutnya Shi et al. (2014) melakukan analisis kestabilan titik ekuilibrium untuk mengetahui bagaimana perilaku model untuk jangka waktu tertentu sehingga dapat diketahui apakah populasi akan bebas dari penyakit atau tidak. Berdasarkan angka rasio reproduksi dasar dapat diketahui faktor-faktor apa saja yang dapat menyebabkan kasus epidemi pada populasi. Salah satu penyakit yang sesuai dengan model Shi et al. (2014) adalah penyakit CVPD pada tanaman jeruk. Oleh karena itu, penulis tertarik untuk mengkaji kembali model Shi et al. (2014) dengan melakukan analisis kestabilan endemik model epidemi CVPD pada tanaman jeruk dengan fungsi respon Holling Tipe II.

\section{HASIL DAN PEMBAHASAN}

Model epidemi CVPD pada tanaman jeruk mengikuti fungsi respon Holling Tipe II. Fungsi Holling Tipe II untuk interaksi mangsa pemangsa diberikan dalam persamaan berikut (Holling, 1959):

$$
g(x)=\frac{a x}{1+h a x}
$$

dengan $h$ menyatakan penanganan dan penangkapan mangsa oleh pemangsa, $g(x)$ menyatakan banyaknya mangsa yang diserang pemangsa per satuan waktu, dan $a$ menyatakan tingkat penangkapan mangsa oleh pemangsa.

Penelitian dilakukan dengan terlebih dahulu menentukan asumsi, variabel, dan parameter pada model (Shi et al., 2014). Selanjutnya, dilakukan penurunan model sesuai dengan asumsi, lalu ditentukan angka rasio reproduksi dasar dan titik ekuilibrium endemik. Nilai $R_{0}$ diperoleh dengan cara menghitung radius spektral dari metode matriks generasi berikutnya (the next generation matrix method) (Brauer et al., 2008). Titik ekuilibrium endemik ditentukan dengan metode substitusi (Edwards dan Penney, 2008). Tahapan selanjutnya adalah melakukan analisis kestabilan di sekitar titik ekuilibrium endemik. Analisis perilaku model dilakukan dengan terlebih dahulu melinierisasi sistem di sekitar 
titik ekuilibrium endemik (Machowski et al., 2008). Selanjutnya, untuk mengetahui kestabilan titik ekuilibrium endemik, dilakukan analisis terhadap bagian riil nilai eigen dari persamaan karakteristik (Edwards dan Penney, 2008). Penentuan bagian riil nilai eigen menggunakan lemma yang berhubungan dengan second additive compound matrix (Muldowney, 2008). Lemma ini digunakan untuk mengecek kestabilan melalui nilai determinan dan trace matriksnya (Shi et al., 2014). Misalkan diberikan $X$ matriks berukuran $3 \times 3$ berikut:

$$
X=\left[\begin{array}{lll}
a_{11} & a_{12} & a_{13} \\
a_{21} & a_{22} & a_{23} \\
a_{31} & a_{32} & a_{33}
\end{array}\right] .
$$

Second additive compound matrix dari matriks $X$ yaitu

$$
X^{[2]}=\left[\begin{array}{lll}
y_{11} & y_{12} & y_{13} \\
y_{21} & y_{22} & y_{23} \\
y_{31} & y_{32} & y_{33}
\end{array}\right]=\left[\begin{array}{ccc}
a_{11}+a_{22} & a_{23} & -a_{13} \\
a_{32} & a_{11}+a_{33} & a_{12} \\
-a_{31} & a_{21} & a_{22}+a_{33}
\end{array}\right] .
$$

Lemma berikut berhubungan dengan second additive compound matrix yang digunakan untuk mengecek bagian riil nilai eigen suatu matriks (Shi et al., 2014).

Lemma 1. Misal M matriks berukuran $3 \times 3$ dengan entri-entri bilangan riil. Jika $\operatorname{tr}(M), \operatorname{det}(M), \operatorname{dan} \operatorname{det}\left(M^{[2]}\right)$ semuanya negatif, maka semua nilai eigen dari matriks $M$ mempunyai bagian riil yang negatif.

Tahapan terakhir adalah melakukan simulasi model dengan menggunakan software Maple. Parameter-parameter dan variabel-variabel yang digunakan dalam simulasi ditentukan berdasarkan data sekunder yang diperoleh dari Balai Pengkajian Teknologi Pertanian (2002), sedangkan parameter dan variabel lainnya dipilih berdasarkan Shi et al. (2014).

Subpopulasi pada model epidemi CVPD dibagi menjadi subpopulasi tanaman jeruk rentan $S$ (susceptible), tanaman jeruk terinfeksi dan menularkan $I$ (infectives), tanaman jeruk sembuh $R$ (recovery), Diaphorina citri rentan $P$, dan 
Diaphorina citri terinfeksi dan menularkan $Y$. Asumsi-asumsi yang digunakan yaitu:

(1) Total jumlah tanaman jeruk konstan setiap saat.

(2) Tingkat kelahiran tanaman jeruk sama dengan tingkat kematian alami tanaman jeruk. Setiap tanaman jeruk yang mati karena penyakit akan digantikan oleh tanaman jeruk baru dengan jumlah yang sama.

(3) Setiap tanaman jeruk baru akan menjadi tanaman jeruk rentan.

(4) Tanaman jeruk rentan tidak hanya dapat terinfeksi oleh Diaphorina citri terinfeksi dan menularkan, tetapi juga oleh tanaman jeruk terinfeksi dan menularkan.

(5) Diaphorina citri rentan hanya dapat terinfeksi oleh tanaman jeruk terinfeksi dan menularkan, dan setelah terinfeksi, Diaphorina citri tersebut akan terus terinfeksi selama sisa hidupnya. Lebih lanjut, diasumsikan tidak terjadi penularan vertikal, yaitu antar serangga Diaphorina citri.

(6) Tingkat kelahiran Diaphorina citri konstan dan setiap Diaphorina citri baru yang lahir akan menjadi Diaphorina citri rentan.

(7) Saat Diaphorina citri rentan menggigit tanaman jeruk terinfeksi, Diaphorina citri tersebut dapat terinfeksi dengan tingkat perpindahan mengikuti Holling Tipe II.

(8) Ketika tanaman jeruk rentan berinteraksi dengan tanaman jeruk terinfeksi, tanaman jeruk tersebut dapat terinfeksi dengan tingkat perpindahan mengikuti Holling Tipe II.

\subsection{Variabel dan Parameter}

Variabel-variabel yang digunakan bernilai nonnegatif, sedangkan parameter-parameternya bernilai positif, yang disajikan dalam tabel berikut. 
Tabel 1. Daftar Variabel dan Parameter

\begin{tabular}{|c|c|c|c|}
\hline Simbol & Definisi & Jenis & Satuan \\
\hline$S$ & Jumlah tanaman jeruk rentan. & Variabel & Pohon \\
\hline$I$ & Jumlah tanaman jeruk terinfeksi dan menularkan. & Variabel & Pohon \\
\hline$R$ & Jumlah tanaman jeruk sembuh. & Variabel & Pohon \\
\hline$K$ & Total jumlah tanaman jeruk. & Variabel & Pohon \\
\hline$P$ & Jumlah Diaphorina citri rentan. & Variabel & Ekor \\
\hline$Q$ & $\begin{array}{l}\text { Jumlah Diaphorina citri terinfeksi dan } \\
\text { menularkan. }\end{array}$ & Variabel & Ekor \\
\hline$N$ & Total jumlah Diaphorina citri. & Variabel & Ekor \\
\hline$\beta_{1}$ & $\begin{array}{l}\text { Rasio infeksi antara tanaman jeruk terinfeksi } \\
\text { dan menularkan dengan Diaphorina citri rentan. }\end{array}$ & Parameter & $\begin{array}{l}\text { Per pohon } \\
\text { per waktu }\end{array}$ \\
\hline$\beta_{2}$ & $\begin{array}{l}\text { Tingkat gigitan Diaphorina citri terinfeksi dan } \\
\text { menularkan terhadap tanaman jeruk rentan. }\end{array}$ & Parameter & $\begin{array}{l}\text { Per ekor per } \\
\quad \text { waktu }\end{array}$ \\
\hline$\beta_{3}$ & $\begin{array}{l}\text { Kejadian infeksi antara tanaman jeruk terinfeksi } \\
\text { dan menularkan dengan tanaman jeruk rentan. }\end{array}$ & Parameter & $\begin{array}{l}\text { Per pohon } \\
\text { per waktu }\end{array}$ \\
\hline$\alpha_{1}$ & $\begin{array}{l}\text { Level kekuatan penyerapan infeksi antara } \\
\text { tanaman jeruk terinfeksi dan menularkan dengan } \\
\text { Diaphorina citri rentan. }\end{array}$ & Parameter & Per pohon \\
\hline$\alpha_{2}$ & $\begin{array}{l}\text { Level kekuatan penyerapan infeksi Diaphorina } \\
\text { citri terinfeksi dan menularkan terhadap tanaman } \\
\text { jeruk rentan. }\end{array}$ & Parameter & Per pohon \\
\hline$\alpha_{3}$ & $\begin{array}{l}\text { Level kekuatan penyerapan infeksi antara } \\
\text { tanaman jeruk terinfeksi dan menularkan dengan } \\
\text { tanaman jeruk rentan. }\end{array}$ & Parameter & Per pohon \\
\hline$\gamma$ & $\begin{array}{l}\text { Tingkat perubahan tanaman jeruk terinfeksi } \\
\text { dan menularkan menjadi tanaman jeruk sembuh } \\
\text { (tingkat kesembuhan). }\end{array}$ & Parameter & Per waktu \\
\hline$\mu$ & Tingkat kematian alami tanaman jeruk. & Parameter & Per waktu \\
\hline$\Lambda$ & Kelahiran atau imigrasi Diaphorina citri. & Parameter & $\begin{array}{l}\text { Ekor per } \\
\text { waktu }\end{array}$ \\
\hline$m$ & Tingkat kematian alami Diaphorina citri. & Parameter & Per waktu \\
\hline$d$ & $\begin{array}{l}\text { Tingkatkematian tanaman jeruk karena } \\
\text { penyakit CVPD. }\end{array}$ & Parameter & Per waktu \\
\hline
\end{tabular}

\subsection{Penurunan Model}

Skema penularan penyakit dari model epidemi CVPD adalah sebagai berikut: 


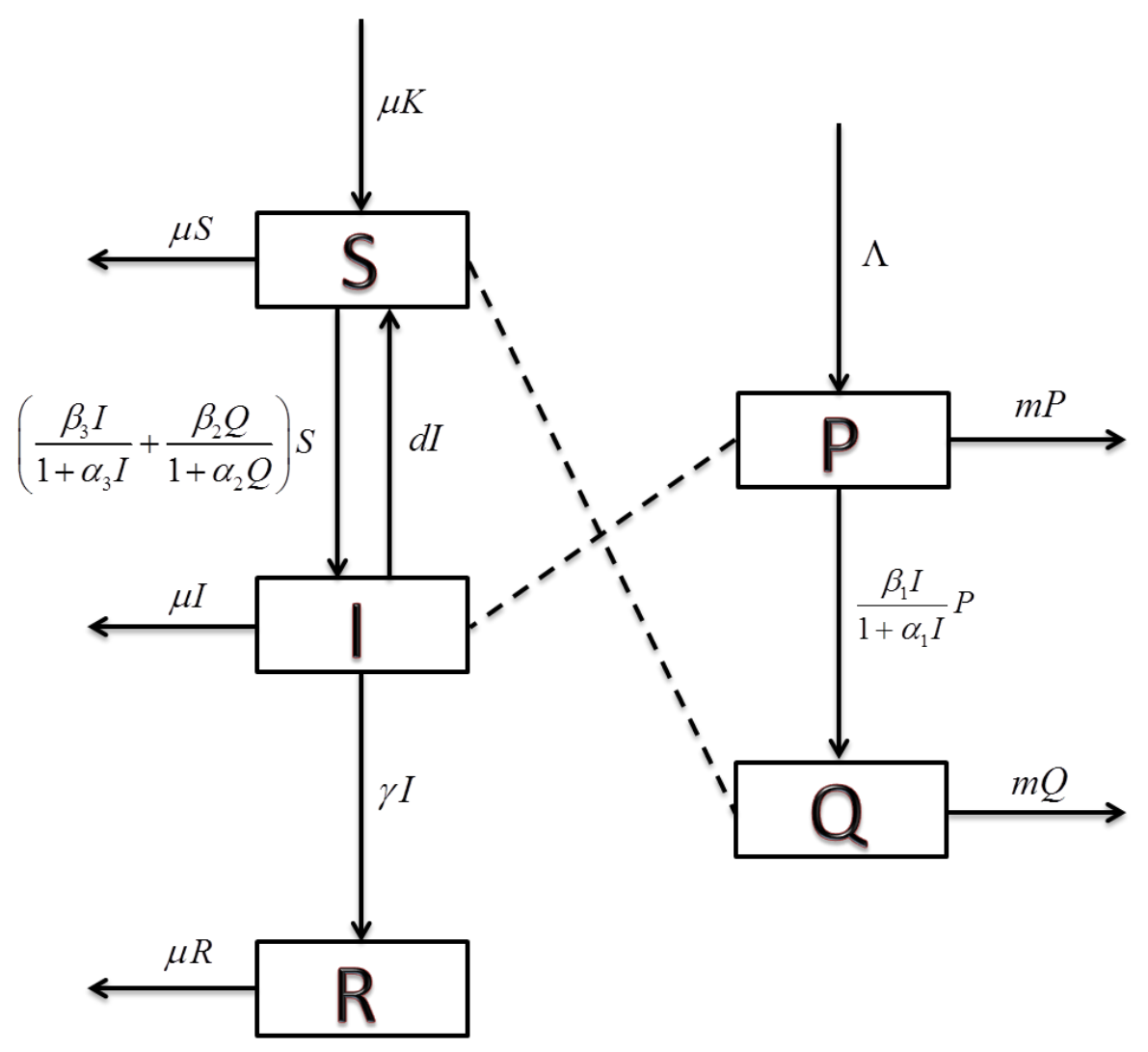

Gambar 1. Diagram Kompartemen Model Epidemi CVPD pada Tanaman Jeruk

Tanda panah pada Gambar 1 menyatakan penambahan atau pengurangan yang terjadi pada masing-masing kompartemen, sedangkan garis putus-putus hanya menyatakan interaksi saja. Berdasarkan Persamaan (1), fungsi respon Holling Tipe II untuk interaksi antara hama dengan tanaman jeruk terlihat pada:

1. Perubahan jumlah $S$ dan perubahan jumlah $I$ yang dipengaruhi oleh banyaknya inang rentan $S$ yang terinfeksi akibat berinteraksi dengan inang terinfeksi dan menularkan $I$ dan hama terinfeksi dan menularkan $Q$ dengan tingkat perpindahan

$$
\frac{\beta_{2} Q}{1+\alpha_{2} Q}+\frac{\beta_{3} I}{1+\alpha_{3} I}
$$

2. Perubahan kepadatan $P$ dan perubahan kepadatan $Q$ yang dipengaruhi oleh banyaknya hama rentan $P$ yang terinfeksi karena menggigit inang terinfeksi dan menularkan $I$ dengan tingkat perpindahan 


$$
\frac{\beta_{1} I}{1+\alpha_{1} I} P
$$

Berdasarkan Gambar 1 diperoleh model epidemi CVPD berupa sistem persamaan diferensial nonlinier yaitu

$$
\begin{aligned}
& \frac{d S}{d t}=\mu(K-S)-\left(\frac{\beta_{2} Q}{1+\alpha_{2} Q}+\frac{\beta_{3} I}{1+\alpha_{3} I}\right) S+d I \\
& \frac{d I}{d t}=\left(\frac{\beta_{2} Q}{1+\alpha_{2} Q}+\frac{\beta_{3} I}{1+\alpha_{3} I}\right) S-(d+\mu+\gamma) I \\
& \frac{d R}{d t}=\gamma I-\mu R \\
& \frac{d P}{d t}=\Lambda-\frac{\beta_{1} I}{1+\alpha_{1} I} P-m P \\
& \frac{d Q}{d t}=\frac{\beta_{1} I}{1+\alpha_{1} I} P-m Q .
\end{aligned}
$$

Diperhatikan bahwa $K=S+I+R$, maka dengan menjumlahkan persamaan pertama, kedua, dan ketiga pada Sistem (3) diperoleh

$$
\frac{d K}{d t}=0
$$

Ini berarti, total jumlah inang untuk setiap saat adalah konstan. Selanjutnya, karena $N=P+Q$, maka dengan menjumlahkan persamaan keempat dan kelima pada Sistem (3) diperoleh

$$
\frac{d N}{d t}=\Lambda-m N
$$

Dengan demikian, untuk $t \rightarrow \infty$ diperoleh $N \rightarrow \frac{\Lambda}{m}$. Dengan kata lain, $\lim _{t \rightarrow \infty} N=\frac{\Lambda}{m}$. Karena untuk $t \rightarrow \infty$, nilai $R$ dapat diperoleh dari $R=K-(S+$ I) dan nilai $P$ dapat diperoleh dari $P=N-Q=\frac{\Lambda}{m}-Q$, maka Sistem (3) dapat direduksi menjadi sistem berikut 


$$
\begin{aligned}
& \frac{d S}{d t}=\mu(K-S)-\left(\frac{\beta_{2} Q}{1+\alpha_{2} Q}+\frac{\beta_{3} I}{1+\alpha_{3} I}\right) S+d I \\
& \frac{d I}{d t}=\left(\frac{\beta_{2} Q}{1+\alpha_{2} Q}+\frac{\beta_{3} I}{1+\alpha_{3} I}\right) S-\omega I \\
& \frac{d Q}{d t}=\frac{\beta_{1} I}{1+\alpha_{1} I}\left(\frac{\Lambda}{m}-Q\right)-m Q
\end{aligned}
$$

dengan $\omega=d+\mu+\gamma$.

Diperhatikan bahwa $S \geq 0, I \geq 0, R \geq 0, P \geq 0$, dan $Q \geq 0$, sehingga $S+I \geq 0$. Selanjutnya, karena $K=S+I+R$, maka $S+I \leq K$. Lebih lanjut, $S+I=K$ terpenuhi jika tidak ada individu di kompartemen $R$. Karena $\frac{\Lambda}{m}=P+Q$, maka $Q \leq \frac{\Lambda}{m}$, sehingga himpunan

$$
\Omega=\left\{(S, I, Q) \in R_{+}^{3}: 0 \leq S+I \leq K, 0 \leq Q \leq \frac{\Lambda}{m}\right\}
$$

adalah himpunan tertutup.

Untuk setiap $\left(S\left(t_{0}\right), I\left(t_{0}\right), Q\left(t_{0}\right)\right) \in \Omega$ dengan $0 \leq S\left(t_{0}\right)+I\left(t_{0}\right) \leq K$ dan $0 \leq Q\left(t_{0}\right) \leq \frac{\Lambda}{m}$, solusi Sistem (4) memenuhi $(S(t), I(t), Q(t)) \in \Omega$ dengan $0 \leq S(t)+I(t) \leq K$ dan $0 \leq Q(t) \leq \frac{\Lambda}{m}$. Jadi, himpunan $\Omega$ adalah himpunan invarian. Karena solusi Sistem (4) memenuhi $(S(t), I(t), Q(t)) \in \Omega$ untuk setiap $t \geq 0$, maka himpunan $\Omega$ adalah himpunan invarian positif, sehingga diperoleh teorema berikut.

Teorema 1. Himpunan tertutup $\Omega$ adalah himpunan invarian positif.

\subsection{Angka Rasio Reproduksi Dasar dan Titik Ekuilibrium Endemik}

Diberikan model pada Sistem (4). Nilai angka rasio reproduksi dasar untuk Sistem (4) diperoleh dengan cara menghitung radius spektral dari metode matriks generasi berikutnya (the next generation matrix method) (Brauer et al., 2008) yaitu 


$$
R_{0}=\frac{\beta_{3} K}{\omega}+\frac{\beta_{1} \beta_{2} \Lambda K}{\omega m^{2}} .
$$

Titik ekuilibrium endemik adalah titik ekuilibrium pada saat terdapat penyakit dan penyakit tersebut menyebabkan epidemi pada populasi (Edwards dan Penney, 2008). Titik ekuilibrium untuk model epidemi CVPD tanaman jeruk pada Sistem (4) diperoleh jika $\frac{d S}{d t}=\frac{d I}{d t}=\frac{d Q}{d t}=0$. Jika dilakukan penjumlahan $\frac{d S}{d t}+\frac{d I}{d t}=0$, maka diperoleh

$$
S=K-\left(1+\frac{\gamma}{\mu}\right) I
$$

Selanjutnya berdasarkan $\frac{d Q}{d t}=0$ diperoleh

$$
Q=\frac{\beta_{1} \Lambda I}{m^{2}\left(1+\alpha_{1} I\right)+m \beta_{1} I} .
$$

Jika Persamaan (5) dan (6) disubstitusikan ke $\frac{d I}{d t}=0$, maka diperoleh

$$
I=\frac{-U+\sqrt{U^{2}-4 T W}}{2 T},
$$

dengan

$$
\begin{aligned}
& T=(\mu+\gamma)\left(\alpha_{3} \beta_{1} \beta_{2} \Lambda+\beta_{3} \alpha_{1} m^{2}+\beta_{3} m \beta_{1}+\beta_{3} \alpha_{2} \beta_{1} \Lambda\right)+\mu \omega\left(\alpha_{1} m^{2} \alpha_{3}+m \beta_{1} \alpha_{3}+\alpha_{2} \beta_{1} \Lambda \alpha_{3}\right) \\
& >0 \text {, } \\
& U=(\mu+\gamma)\left(\beta_{1} \beta_{2} \Lambda+\beta_{3} m^{2}\right)+\mu \omega\left(\alpha_{1} m^{2}+m \beta_{1}+\alpha_{2} \beta_{1} \Lambda+m^{2} \alpha_{3}\right) \\
& -\mu K\left(\alpha_{3} \beta_{1} \beta_{2} \Lambda+\beta_{3} \alpha_{1} m^{2}+\beta_{3} m \beta_{1}+\beta_{3} \alpha_{2} \beta_{1} \Lambda\right), \\
& W=m^{2} \omega \mu\left(1-R_{0}\right)
\end{aligned}
$$

dan $R_{0}>1$. Dengan demikian, diperoleh titik ekuilibrium endemik dari Sistem (4) yang ditulis dalam teorema berikut. 
Teorema 2. Titik ekuilibrium endemik dari Sistem (4) yaitu $E_{1}=\left(S^{*}, I^{*}, Q^{*}\right)$, dengan $S^{*}=K-\left(1+\frac{\gamma}{\mu}\right) I^{*}, \quad I^{*}=\frac{-U+\sqrt{U^{2}-4 T W}}{2 T}, Q^{*}=\frac{\beta_{1} \Lambda I^{*}}{m^{2}\left(1+\alpha_{1} I^{*}\right)+m \beta_{1} I^{*}}$.

\subsection{Analisis Perilaku Model}

Matriks Jacobian hasil linierisasi model epidemi tanaman di sekitar titik ekuilibrium $E=\left(S^{*}, I^{*}, Q^{*}\right)$ (Machowski et al., 2008) adalah

$$
J_{(E)}=\left(\begin{array}{ccc}
G_{1} & d-\frac{\beta_{3} S}{\left(1+\alpha_{3} I\right)^{2}} & -\frac{\beta_{2} S}{\left(1+\alpha_{2} Q\right)^{2}} \\
G_{2} & \frac{\beta_{3} S}{\left(1+\alpha_{3} I\right)^{2}}-\omega & \frac{\beta_{2} S}{\left(1+\alpha_{2} Q\right)^{2}} \\
0 & \frac{\beta_{1} \Lambda}{m\left(1+\alpha_{1} I\right)^{2}}-\frac{\beta_{1} Q}{\left(1+\alpha_{1} I\right)^{2}} & -\frac{\beta_{1} I}{1+\alpha_{1} I}-m
\end{array}\right)_{(S, I, Q)=\left(S^{*}, I^{*}, Q^{*}\right)}
$$

dengan

$$
G_{1}=-\mu-\left(\frac{\beta_{2} Q}{1+\alpha_{2} Q}+\frac{\beta_{3} I}{1+\alpha_{3} I}\right), G_{2}=\frac{\beta_{2} Q}{1+\alpha_{2} Q}+\frac{\beta_{3} I}{1+\alpha_{3} I}
$$

Matriks $J_{\left(E_{1}\right)}$ adalah matriks Jacobian di sekitar titik $E_{1}=\left(S^{*}, I^{*}, Q^{*}\right)$, yaitu

$$
J_{\left(E_{1}\right)}=\left(\begin{array}{ccc}
M_{1} & d-\frac{\beta_{3} S^{*}}{\left(1+\alpha_{3} I^{*}\right)^{2}} & -\frac{\beta_{2} S^{*}}{\left(1+\alpha_{2} Q^{*}\right)^{2}} \\
M_{2} & \frac{\beta_{3} S^{*}}{\left(1+\alpha_{3} I^{*}\right)^{2}}-\omega & \frac{\beta_{2} S^{*}}{\left(1+\alpha_{2} Q^{*}\right)^{2}} \\
0 & \left(\frac{\Lambda}{m}-Q^{*}\right) \frac{\beta_{1}}{\left(1+\alpha_{1} I^{*}\right)^{2}} & -\frac{\beta_{1} I^{*}}{1+\alpha_{1} I^{*}}-m
\end{array}\right),
$$

dengan

$$
M_{1}=-\mu-\left(\frac{\beta_{2} Q^{*}}{1+\alpha_{2} Q^{*}}+\frac{\beta_{3} \cdot I^{*}}{1+\alpha_{3} I^{*}}\right), M_{2}=\frac{\beta_{2} Q^{*}}{1+\alpha_{2} Q^{*}}+\frac{\beta_{3} \cdot I^{*}}{1+\alpha_{3} I^{*}} .
$$

Berdasarkan Persamaan (2), diperoleh second additive compound matrix untuk matriks $J_{\left(E_{1}\right)}$ (Muldowney, 2008) yaitu 


$$
J_{\left(E_{1}\right)}^{[2]}=\left(\begin{array}{ccc}
D_{11} & \frac{\beta_{2} S^{*}}{\left(1+\alpha_{2} Q^{*}\right)^{2}} & \frac{\beta_{2} S^{*}}{\left(1+\alpha_{2} Q^{*}\right)^{2}} \\
\left(\frac{\Lambda}{m}-Q^{*}\right) \frac{\beta_{1}}{\left(1+\alpha_{1} I^{*}\right)^{2}} & D_{22} & d-\frac{\beta_{3} S^{*}}{\left(1+\alpha_{3} I^{*}\right)^{2}} \\
0 & \frac{\beta_{2} Q^{*}}{1+\alpha_{2} Q^{*}}+\frac{\beta_{3} I^{*}}{1+\alpha_{3} I^{*}} & D_{33}
\end{array}\right),
$$

dengan

$$
\begin{aligned}
& D_{11}=-\mu-\left(\frac{\beta_{2} Q^{*}}{1+\alpha_{2} Q^{*}}+\frac{\beta_{3} I^{*}}{1+\alpha_{3} I^{*}}\right)+\frac{\beta_{3} S^{*}}{\left(1+\alpha_{3} I^{*}\right)^{2}}-\omega, \\
& D_{22}=-\mu-\left(\frac{\beta_{2} Q^{*}}{1+\alpha_{2} Q^{*}}+\frac{\beta_{3} I^{*}}{1+\alpha_{3} I^{*}}+\frac{\beta_{1} I^{*}}{1+\alpha_{1} I^{*}}+m\right), \\
& D_{33}=\frac{\beta_{3} S^{*}}{\left(1+\alpha_{3} I^{*}\right)^{2}}-\omega-\frac{\beta_{1} I^{*}}{1+\alpha_{1} I^{*}}-m .
\end{aligned}
$$

Nilai $\operatorname{tr}\left(J_{\left(E_{1}\right)}\right)<0, \quad \operatorname{det}\left(J_{\left(E_{1}\right)}\right)<0, \quad \operatorname{dan} \operatorname{det}\left(J_{\left(E_{1}\right)}^{[2]}\right)<0$, sehingga berdasarkan Lemma 1, semua nilai eigen dari matriks $M$ mempunyai bagian riil yang negatif. Perhatikan kembali bahwa titik ekuilibrium endemik $E_{1}$ diperoleh saat $R_{0}>1$ sehingga diperoleh kestabilan titik ekulibrium $E_{1}$ yang ditulis dalam teorema berikut.

Teorema 3. Dimisalkan $E_{1}=\left(S^{*}, I^{*}, Q^{*}\right)$, dengan

$$
S^{*}=K-\left(1+\frac{\gamma}{\mu}\right) I^{*}, I^{*}=\frac{-U+\sqrt{U^{2}-4 T W}}{2 T}, Q^{*}=\frac{\beta_{1} \Lambda I^{*}}{m^{2}\left(1+\alpha_{1} I^{*}\right)+m \beta_{1} I^{*}} .
$$

Jika $R_{0}>1$, maka titik ekuilibrium endemik $E_{1}$ stabil asimtotik lokal.

Hal ini berarti jika $R_{0}>1$ maka penyakit akan menyebar. Dengan kata lain terjadi epidemi pada populasi. 


\subsection{Simulasi Model}

Menurut Balai Pengkajian Teknologi Pertanian (2002), vektor Diaphorina citri mampu menghasilkan 9-10 generasi dalam 1 tahun, sehingga diperoleh nilai parameter $\Lambda=10$ ekor per tahun. Berdasarkan pengamatan Wijaya et al. (2010), kisaran populasi Diaphorina citri adalah 0,12-9,9 ekor per pohon, sehingga dipilih populasi awal Diaphorina citri yang terinfeksi dan menularkan sebanyak 10 ekor. Nilai-nilai parameter lainnya dipilih berdasarkan jurnal Shi et al. (2014). Nilai-nilai parameter disajikan dalam tabel berikut.

Tabel 2. Nilai-nilai Parameter

\begin{tabular}{|c|c|c|c|}
\hline Simbol & Definisi & Nilai & Satuan \\
\hline $\bar{\beta}$ & $\begin{array}{l}\text { Rasio infeksi antara tanaman jeruk terinfeksi dan } \\
\text { menularkan dengan Diaphorina citri rentan. }\end{array}$ & 0,01 & $\begin{array}{l}\text { Per pohon } \\
\text { per tahun }\end{array}$ \\
\hline$\beta_{2}$ & $\begin{array}{l}\text { Tingkat gigitan Diaphorina citri terinfeksi dan } \\
\text { menularkan terhadap tanaman jeruk rentan. }\end{array}$ & 0,02 & $\begin{array}{l}\text { Per ekor } \\
\text { per tahun }\end{array}$ \\
\hline $\bar{\beta}$ & $\begin{array}{l}\text { Kejadian infeksi antara tanaman jeruk terinfeksi dan } \\
\text { menularkan dengan tanaman jeruk rentan. }\end{array}$ & 0,01 & $\begin{array}{l}\text { Per pohon } \\
\text { per tahun }\end{array}$ \\
\hline$\alpha_{1}$ & $\begin{array}{l}\text { Level kekuatan penyerapan infeksi antara tanaman } \\
\text { jeruk terinfeksi dan menularkan dengan Diaphorina } \\
\text { citri rentan. }\end{array}$ & 0,1 & Per pohon \\
\hline$\alpha_{2}$ & $\begin{array}{l}\text { Level kekuatan penyerapan infeksi Diaphorina citri } \\
\text { terinfeksi dan menularkan terhadap tanaman jeruk } \\
\text { rentan. }\end{array}$ & 0,2 & Per pohon \\
\hline$\alpha_{3}$ & $\begin{array}{l}\text { Level kekuatan penyerapan infeksi antara tanaman } \\
\text { jeruk terinfeksi dan menularkan dengan tanaman jeruk } \\
\text { rentan. }\end{array}$ & 0,2 & Per pohon \\
\hline$\gamma$ & $\begin{array}{l}\text { Tingkat perubahan tanaman jeruk terinfeksi dan } \\
\text { menularkan menjadi tanaman jeruk sembuh (tingkat } \\
\text { kesembuhan). }\end{array}$ & 0,065 & Per tahun \\
\hline$\mu$ & Tingkat kematian alami tanaman jeruk. & 0,1 & Per tahun \\
\hline$\Lambda$ & Kelahiran atau imigrasi Diaphorina citri. & 10 & $\begin{array}{l}\text { Ekor per } \\
\text { tahun }\end{array}$ \\
\hline$m$ & Tingkat kematian alami Diaphorina citri. & 0,3 & Per tahun \\
\hline$d$ & $\begin{array}{l}\text { Tingkat kematian tanaman jeruk karena penyakit } \\
\text { CVPD. }\end{array}$ & 0,1 & Per tahun \\
\hline
\end{tabular}

dengan nilai awalnya adalah $S(0)=700, I(0)=200, Q(0)=10$, dan total jumlah pohon jeruk $K=1.000$. 
Berdasarkan Tabel 2, diperoleh nilai angka rasio reproduksi dasar yaitu $R_{0}=121,6>1$. Karena $R_{0}>1$, maka penyakit akan menyebar. Dengan kata lain akan terjadi epidemi pada populasi. Titik ekuilibrium endemiknya adalah $E_{1}=(589,249,8)$. Hasil simulasi di titik ekuilibrium $E_{1}$ dengan menggunakan software Maple disajikan dalam gambar berikut.

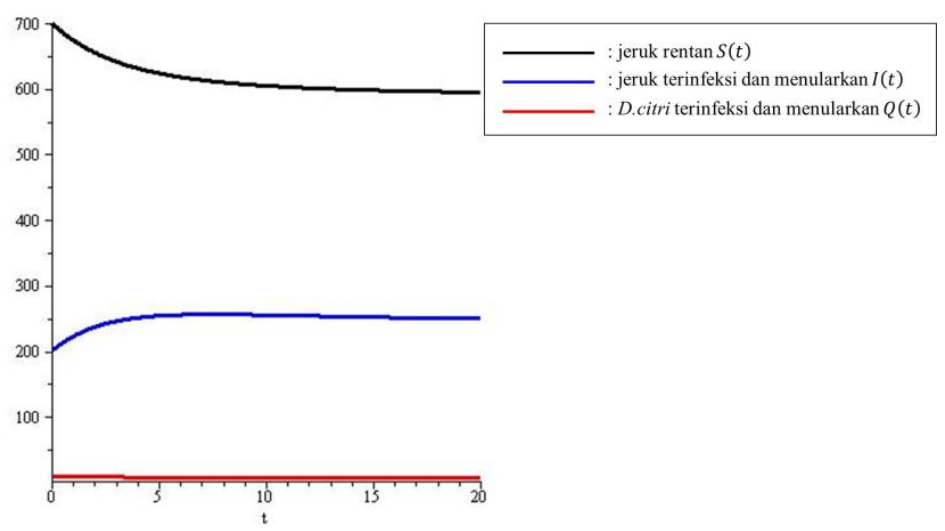

Gambar 2. Grafik $S, I$, dan $Q$ di Titik Ekuilibrium $E_{1}$

Berdasarkan Gambar 2, jumlah jeruk rentan $S$, jeruk terinfeksi dan menularkan $I$, serta Diaphorina citri terinfeksi dan menularkan $Q$ untuk jangka waktu tertentu akan menuju ke titik ekuilibrium endemik $E_{1}$. Dengan demikian,, terjadi epidemi pada populasi. Selanjutnya, jumlah jeruk sembuh $R$ lebih kurang 162 pohon dan jumlah $D$. citri rentan $P$ lebih kurang 25 ekor. Jadi, berdasarkan data yang digunakan, penyakit CVPD akan menyebar atau terjadi epidemi pada populasi jeruk.

Berdasarkan angka rasio reproduksi dasar, faktor-faktor yang dapat dikendalikan agar penyakit tidak mewabah diantaranya rasio infeksi antara jeruk terinfeksi dan menularkan dengan Diaphorina citri rentan $\left(\beta_{1}\right)$, tingkat gigitan Diaphorina citri terinfeksi dan menularkan terhadap jeruk rentan $\left(\beta_{2}\right)$, dan kejadian infeksi antara jeruk terinfeksi dan menularkan dengan jeruk rentan $\left(\beta_{3}\right)$. Paramater $\beta_{1}$ dapat dikendalikan dengan cara pemusnahan tanaman sakit. Paramater $\beta_{2}$ dapat dikendalikan dengan cara penggunaan pestisida yang dapat 
mengendalikan populasi vektor. Paramater $\beta_{3}$ dapat dikendalikan dengan cara pengadaan bibit jeruk bebas penyakit.

\section{KESIMPULAN DAN SARAN}

Model epidemi CVPD pada tanaman jeruk dengan fungsi respon Holling Tipe II memiliki satu titik ekuilibrium endemik. Angka rasio reproduksi dasar menunjukkan bahwa penyebaran penyakit dalam populasi dipengaruhi oleh rasio infeksi antara tanaman jeruk terinfeksi dan menularkan dengan Diaphorina citri rentan, tingkat gigitan Diaphorina citri terinfeksi dan menularkan terhadap tanaman jeruk rentan, kejadian infeksi antara tanaman jeruk terinfeksi dan menularkan dengan tanaman jeruk rentan, tingkat perubahan tanaman jeruk terinfeksi dan menularkan menjadi tanaman jeruk sembuh (tingkat kesembuhan), tingkat kematian alami tanaman jeruk, kelahiran atau imigrasi Diaphorina citri, tingkat kematian alami Diaphorina citri, dan tingkat kematian tanaman jeruk karena penyakit CVPD. Analisis perilaku model menunjukkan bahwa titik ekuilibrium endemik $E_{1}$ bersifat stabil asimtotik lokal jika nilai angka rasio reproduksi dasar lebih dari satu. Ini berarti jika nilai angka rasio reproduksi dasar lebih dari satu maka penyakit akan mewabah. Pengendalian yang dapat dilakukan agar penyakit CVPD tidak mewabah diantaranya dengan cara pemusnahan tanaman sakit, penggunaan pestisida yang dapat mengendalikan populasi vektor, dan pengadaan bibit jeruk bebas penyakit.

\section{DAFTAR PUSTAKA}

Balai Pengkajian Teknologi Pertanian, Pengenalan Penyakit CVPD pada Tanaman Jeruk dan Upaya Pengendaliannya, Sulawesi Selatan, 2002, http://sulsel.litbang.pertanian.go.id/ind/index.php?option=com_content\&vi ew=article\&id=121:pengenalan-penyakit-cvpd-pada-tanaman-jeruk-danupaya-pengendaliannya\&catid=47: panduanpetunjuk-teknis-brosur\&Itemid=231, diakses pada 5 Desember 2016.

Brauer, F., Driessche, P. Van Den, dan Wu, J., Mathematical Epidemiology, Springer, Verlag Berlin Heidelberg, 2008. 
Edwards, C. H. dan Penney, D. E., Elementary Differential Equation, Edisi Keempat, Pearson Education, New Jersey, 2008.

Holling, C. S., Some characteristics of simple types of predation and parasitism, Entomology Journal Canada, 91 (1959), 385-398.

Ma, Z. dan Li, J., Dinamical Modeling and Analysis of Epidemics, World Scientific Publisher, Singapore, 2009.

Machowski, J., Bialek, J. W., dan Bumby, J. R., Power System Dynamics: Stability and Control, Edisi Kedua, John Wiley and Sons, Inc., New York, 2008 .

Muldowney, J. S., Compound matrices and ordinary differential equations, Rocky Mountain Mathematics Consortium, 20(4) (1990), 1-16.

Olsder, G. J., Woude, J. W. van der, Maks, J. G., dan Jeltsema, D., Mathematical Systems Theory, Edisi Keempat, VSSD, Netherlands, 2011.

Rizal. M., Pebriyadi, B., dan Widowati, R., Budidaya Jeruk Bebas Penyakit, Kalimantan Timur, 2011.

Shi, R., Zhao, H., dan Tang, S., Global dynamic analysis of a vector-borne plant disease model, Springer, 59 (2014), 1-16.

Wijaya, I. N., Adiartayasa, W., Sritamin, M., Ketut, D. A. N., dan Yuliadhi, A. Y. U., Dinamika populasi Diaphorina citri Kuwayama (Homoptera: Psyllidae) dan deteksi CVPD dengan teknik PCR, Jurnal Entomologi Indonesia, 7(2) (2010), 78-87. 